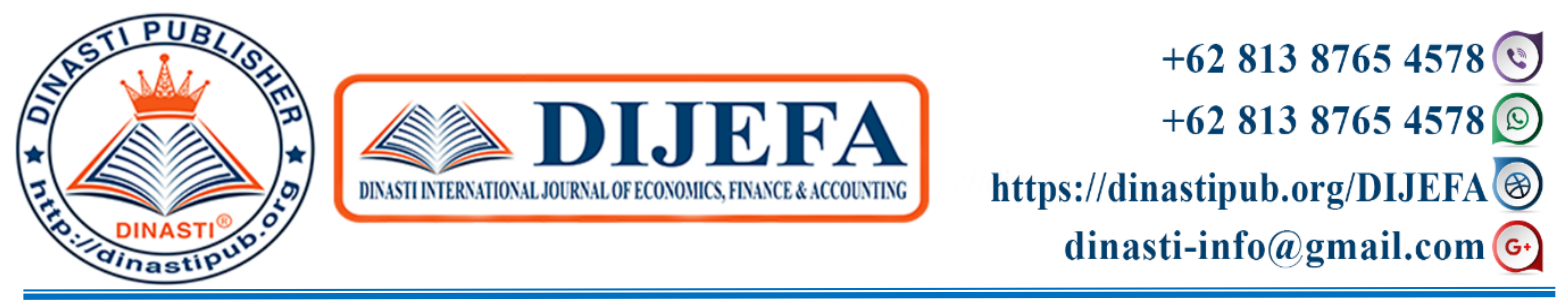

\title{
THE EFFECT OF INTRINSIC MOTIVATION AND ORGANIZATIONAL CULTURE ON EMPLOYEE ENGAGEMENT MEDIATED PERFORMANCE AT PT XYZ
}

\author{
Ridwan Arifin ${ }^{1)}$, Singmin Johanes Lo ${ }^{2)}$ \\ ${ }^{1,2}$ Mercu Buana University, Jakarta, Indonesia
}

\begin{tabular}{|c|c|}
\hline 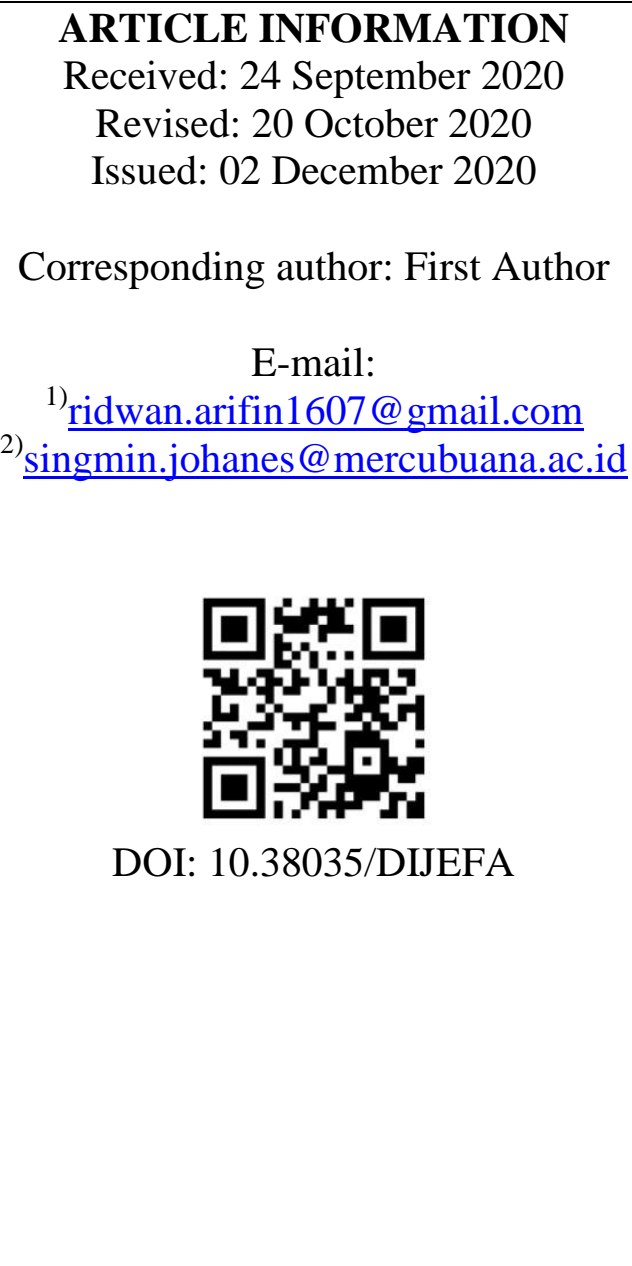 & $\begin{array}{l}\text { Abstract: This study aims to analyze the influence of } \\
\text { intrinsic motivation and organizational culture on } \\
\text { employee performance mediated by employee } \\
\text { engagement. The object of this research is the } \\
\text { employees of PT XYZ. A total of } 100 \text { respondents filled } \\
\text { out a questionnaire, the sample was taken using a } \\
\text { saturated sample of } 100 \text { employees. This research was } \\
\text { conducted from October } 2019 \text { to April } 2020 \text { at the PT } \\
\text { XYZ office. The sampling technique used was saturated } \\
\text { sampling. Data were analyzed using the Smart PLS } \\
\text { (Partial Least Square) path analysis application. The } \\
\text { results of this study indicate that Intrinsic Motivation } \\
\text { and Organizational Culture have a positive and } \\
\text { significant effect on performance. Meanwhile Employee } \\
\text { Engagement becomes a mediation between Intrinsic } \\
\text { Motivation and Organizational Culture on Performance. } \\
\text { Employee Engagement perfectly mediates Intrinsic } \\
\text { Motivation. And Employee Engagement partially } \\
\text { mediates Organizational Culture. } \\
\text { Keywords: Intrinsic Motivation, Organizational } \\
\text { Culture, Employee Engagement, Employee } \\
\text { Performance. }\end{array}$ \\
\hline
\end{tabular}

\section{INTRODUCTION}

The rapid development of technology and information at this time demands that every company must strive to always be a superior company in its field to face increasingly fierce business competition. As a result, PT XYZ is faced with big challenges in order to survive, therefore, the company needs to carry out various kinds of appropriate strategies to be able to compete with competing companies. The success of a company in achieving this goal cannot be separated from the existence of human resources or human capital in it, which plays a very important role in running a business to meet the needs of the company in achieving its goals. 


\section{Background}

PT XYZ is one of the foreign companies located in Indonesia, with a core business as a telecommunication solution provider created as a result of the combination of the COM Division of Siemens AG and the Network business group Nokia. The company announced its founding on June 19, 2006. The Nokia Networks identity was created by the branding company Moving Brands, which is based in London and Tokyo, within 2 months and first launched at the 3GSM World Congress at Barcelona in February 2007. PT XYZ as a network provider company where employees have highly skilled competences in their fields and have good loyalty to the company, so that the company pays close attention to the competence of its employees for the progress of the company. This explain why it can compete with similar competitor companies such as Huawei, Ericson, and ZTE. In this case, PT XYZ understands that employees with good skills and competencies are very valuable assets for the company.

The results of interviews with key persons were interview results regarding the decline in employee performance due to a lack of career development programs provided by the company, which resulted in low intrinsic motivation. And the lack of seriousness of employees in working so that they can finish their work until completion, so that it has an impact on low employee engagement or employee engagement. In addition, it is also based on interviews with key persons who reveal the lack of input from others to evaluate work. This has an impact on the low quality of organizational culture at PT XYZ.

Previous research also found the relationship between these problems. Research of Ridwan Isya Luthfi, Heru Susilo and Muhammad Faisal Riza, explains that intrinsic motivation has a positive and significant effect on employee performance [1]. Aditia Rachmatullah also shows that intrinsic motivation has a significant effect on employee engagement by 48-\% [2], research by Alinvia Ayu Sagita, Heru Susilo and Muhammad Cahyo WS, which states that implementing a suitable organizational culture will have a positive impact on work motivation there by increasing employee performance in the company. [3] The research conducted by Agnes Wahyu Handoyo and Roy Setiawan states that employee engagement is determined by work environment, leadership, team and coworkers, training and career development, compensation, organizational policies, and work welfare. The results of this study indicate that employee engagement has a positive and significant effect on employee performance [4].

From the description above, it appears that the intrinsic motivation and organizational culture are not optimal so that employee engagement is low, which ultimately results in suboptimal employee performance. Based on this background, we are interested in conducting research related to "The Effect of Intrinsic Motivation and Organizational Culture on Employee Performance Mediated by Employee Engagement at PT XYZ."

\section{LITERATURE REVIEW}

\section{Intrinsic Motivation}


Herzberg in Tjahjono (2003) explains that there are two types of factors that encourage a person to try to achieve satisfaction and keep away from dissatisfaction. The two factors are called motivator factors (intrinsic factors) and hygiene factors (extrinsic factors). Intrinsic motivation consists of 3 factors, namely job performance, recognition, and increasing responsibility [5].

\section{Organizational culture}

According to Hofstede (2001) "Dimension of culture is The comparison of cultures presupposes that there is something to be compared - that each culture is not so unique that any parallel with another culture is meaningless." This understanding can be understood that cultural comparison presupposes that there is something to be compared - that every culture is not so unique, that every culture that is parallel to other cultures does not have that meaningful meaning. The following are the cultural dimensions constructed by Hofstede and other researchers: 1. Power distance, 2. Individualism / collectivism, 3. Masculinity / feminity, 4. Uncertainty avoidance [6].Employee Engagement

Employee engagement is a condition, positive attitude or behavior of an employee towards the job and organization which is characterized by feelings of enthusiasm (vigor), dedication and preoccupation (absorption) to achieve organizational goals and success. According to Schaufeli and Bakker (2004), employee engagement is positive thinking, namely thoughts of completing work-related things and characterized by vigor (energy and mental resilience at work), dedication (participating in work experiencing a sense of enthusiasm and challenges), and absorption. (Concentration and happy at work) [7].

\section{Employee performance}

According to Sedarmayanti (2009: 50) the definition of employee performance in his book "Sumber Daya Manusia dan Produktivitas Kerja", namely: "How an employee performs his job or for work. Increased employee performance will also affect the improvement of the performance of the organization where the employee works, so that the organizational goals that have been determined can be achieved" [8].

The Research Conceptual Framework Model is described as follows:

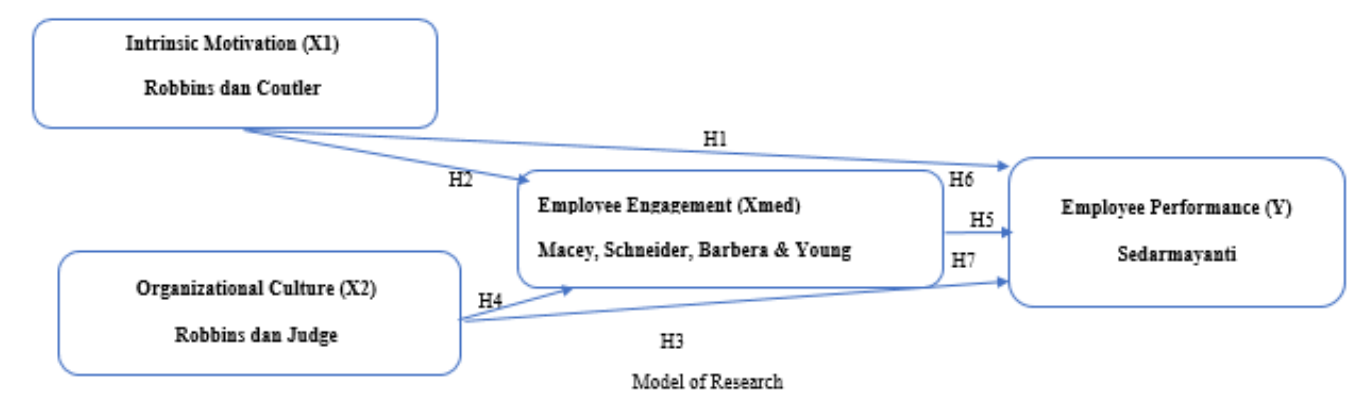

\section{Hypothesis}


H1: Intrinsic motivation has a significant effect on employee performance.

$\mathrm{H} 2$ : Intrinsic motivation has a significant effect on employee engagement.

H3: Organizational culture has a significant effect on employee performance.

H4: Organizational culture has a significant effect on employee engagement.

H5: Employee engagement has a significant effect on employee performance.

H6: Intrinsic motivation has a significant effect on employee performance which is mediated by employee engagement.

H7: Organizational culture has a significant effect on employee performance mediated by employee engagement.

\section{RESEARCH METHOD}

The method used in this research is a descriptive method with a quantitative approach and a causal research method. The object of this research is the employees of the head office of PT XYZ. A total of 100 respondents filled out the questionnaire. The sampling technique used was saturated samples. Data were analyzed using the Smart PLS (Partial Least Square) path analysis application.

\section{RESULTS AND DISCUSSION}

\section{Frequency Distribution}

Based on the results of the questionnaire that had been distributed, it was found that men were $61 \%$, while women were $39 \%$. In terms of education, it is dominated by employees with a bachelor's degree (S1) as many as 64\%; employees with a Diploma Three (D3) education as many as 28\%; while employees with a high school education / equivalent are 5\%; and employees with a Strata Two education (S2) as many as 3\%. In terms of age, $45 \%$ are dominated by employees aged 30 to 40 years; employees over 41 years old are 30\%; while employees aged 20 to 30 years are $25 \%$. Meanwhile, for the length of work, there are $58 \%$ of employees who have been working 5 to 10 years, $20 \%$ of employees who have been working 1 to 5 years, while $12 \%$ of employees who have been working more than 1 year.

\section{Evaluation of the Outer Model}

According to Ghozali \& Latan, an indicator is considered to have a high level of validity if it has a loading factor value greater than 0.70 . However, the loading factor of 0.50 to 0.60 is still acceptable. The loading factor value used in this study is $>0.6$ so that if the loading factor value is $<0.6$ in the calculation result of the measurement model (outer model), it will be excluded from the model and recalculated in the measurement model (outer model). 
Table.1 Convergent Validity 1

\begin{tabular}{|c|c|c|c|c|c|}
\hline Variabel & Indikator & Outer Loading & Variabel & Indikator & Outer Loading \\
\hline \multirow{12}{*}{$\begin{array}{c}\text { Intrinsic } \\
\text { Motivation (X1) }\end{array}$} & M1 & 0.808 & \multirow{14}{*}{$\begin{array}{l}\text { Organizational } \\
\text { Culture (X2) }\end{array}$} & $\mathrm{BO} 1$ & 0.432 \\
\hline & $\mathrm{M} 2$ & 0.778 & & $\mathrm{BO} 2$ & 0.774 \\
\hline & M3 & 0.757 & & $\mathrm{BO} 3$ & 0.821 \\
\hline & M4 & 0.587 & & $\mathrm{BO} 4$ & 0.797 \\
\hline & M5 & 0.694 & & $\frac{\mathrm{D} 4}{\mathrm{BO} 5}$ & 0.760 \\
\hline & M6 & 0.696 & & BO6 & 0.777 \\
\hline & M7 & 0.641 & & $\mathrm{BO} 7$ & 0.078 \\
\hline & M8 & 0.693 & & BO8 & 0.820 \\
\hline & M9 & 0.244 & & $\mathrm{BO9}$ & 0.785 \\
\hline & $\mathrm{M} 10$ & 0.783 & & $\mathrm{BO} 10$ & 0.759 \\
\hline & & & & BO11 & 0.713 \\
\hline & & & & $\mathrm{BO} 12$ & 0.633 \\
\hline Variabel & Indikator & Outer Loading & & $\mathrm{BO} 13$ & 0.814 \\
\hline \multirow{14}{*}{$\begin{array}{c}\text { Employee } \\
\text { Engagement } \\
\text { (Xmed) }\end{array}$} & E1 & 0.718 & & $\mathrm{BO} 14$ & 0.651 \\
\hline & E2 & 0.671 & & & \\
\hline & E3 & 0.602 & Variabel & Indikator & Outer Loading \\
\hline & E4 & 0.348 & \multirow{11}{*}{$\begin{array}{c}\text { Employee } \\
\text { Performance }(\mathrm{Y})\end{array}$} & & \\
\hline & E5 & 0.875 & & K1 & 0.576 \\
\hline & E6 & 0.789 & & $\mathrm{~K} 2$ & 0.845 \\
\hline & E7 & 0.888 & & $\mathrm{~K} 3$ & 0.876 \\
\hline & E8 & 0.719 & & $\mathrm{~K} 4$ & 0.915 \\
\hline & E9 & 0.529 & & K5 & 0.941 \\
\hline & E10 & 0.571 & & K6 & 0.908 \\
\hline & E11 & 0.860 & & K7 & 0.705 \\
\hline & E12 & 0.712 & & $\mathrm{~K} 8$ & 0.820 \\
\hline & E13 & 0.844 & & K9 & -0.566 \\
\hline & E14 & 0.725 & & & \\
\hline
\end{tabular}

Based on the first calculation, there are several indicators that are invalid, so they are removed from the model then the second calculation is carried out.

Table.2 Convergent Validity 2

\begin{tabular}{|c|c|c|}
\hline Variabel & Indikator & $\begin{array}{c}\text { Outer Loading } \\
\text { Value }\end{array}$ \\
\hline \multirow{8}{*}{$\begin{array}{c}\text { Intrinsic } \\
\text { Motivation (X1) }\end{array}$} & M1 & 0.832 \\
\hline & M2 & 0.786 \\
\hline & M3 & 0.733 \\
\hline & M5 & 0.688 \\
\hline & M6 & 0.720 \\
\hline & M7 & 0.657 \\
\hline & M8 & 0.692 \\
\hline & M10 & 0.797 \\
\hline Variabel & Indikator & Outer Loading \\
\hline \multirow{11}{*}{$\begin{array}{l}\text { Employee } \\
\text { Engagement } \\
\text { (Xmed) }\end{array}$} & E1 & 0.716 \\
\hline & E2 & 0.669 \\
\hline & E3 & 0.594 \\
\hline & E5 & 0.878 \\
\hline & E6 & 0.803 \\
\hline & E7 & 0.894 \\
\hline & E8 & 0.696 \\
\hline & E11 & 0.865 \\
\hline & E12 & 0.728 \\
\hline & E13 & 0.855 \\
\hline & E14 & 0.740 \\
\hline
\end{tabular}

\begin{tabular}{|c|c|c|}
\hline Variabel & Indikator & $\begin{array}{c}\text { Outer Loading } \\
\text { Value }\end{array}$ \\
\hline \multirow{12}{*}{$\begin{array}{l}\text { Organizational } \\
\text { Culture (X2) }\end{array}$} & $\mathrm{BO} 2$ & 0.773 \\
\hline & $\mathrm{BO} 3$ & 0.821 \\
\hline & $\mathrm{BO4}$ & 0.797 \\
\hline & $\mathrm{BO5}$ & 0.757 \\
\hline & BO6 & 0.774 \\
\hline & $\mathrm{BOS}$ & 0.818 \\
\hline & BO9 & 0.790 \\
\hline & BO10 & 0.763 \\
\hline & B011 & 0.715 \\
\hline & $\mathrm{BO} 12$ & 0.632 \\
\hline & $\mathrm{BO} 13$ & 0.811 \\
\hline & $\mathrm{BO} 14$ & 0.657 \\
\hline Variabel & Indikator & Outer Loading \\
\hline \multirow{7}{*}{$\begin{array}{c}\text { Employee } \\
\text { Performance }(\mathrm{Y})\end{array}$} & $\mathrm{K} 2$ & 0.819 \\
\hline & $\mathrm{K} 3$ & 0.876 \\
\hline & K4 & 0.928 \\
\hline & $\mathrm{K} 5$ & 0.951 \\
\hline & K6 & 0.927 \\
\hline & K7 & 0.717 \\
\hline & K8 & 0.826 \\
\hline
\end{tabular}

Based on the second calculation, there is one invalid indicator on the employee engagement variable, so it is removed from the model then the third calculation is carried out. 
Table. 3 Convergent Validity 3

\begin{tabular}{ccc}
\hline Variabel & Indikator & Outer Loading \\
\hline \multirow{4}{*}{ Intrinsic } & M1 & 0.832 \\
\cline { 2 - 3 } Motivation (X1) & M2 & 0.786 \\
\cline { 2 - 3 } & M3 & 0.732 \\
\cline { 2 - 3 } & M5 & 0.687 \\
\cline { 2 - 3 } & M6 & 0.721 \\
\cline { 2 - 3 } & M8 & 0.656 \\
\hline \multirow{5}{*}{ Variabel } & M10 & 0.693 \\
\hline & & 0.797 \\
\hline & Indikator & Outer Loading \\
\cline { 2 - 3 } & E2 & 0.694 \\
\cline { 2 - 3 } Employee & E5 & 0.628 \\
\cline { 2 - 3 } Engagement & E6 & 0.889 \\
\cline { 2 - 3 } (Xmed) & E7 & 0.809 \\
\cline { 2 - 3 } & E8 & 0.904 \\
\cline { 2 - 3 } & E11 & 0.706 \\
\cline { 2 - 3 } & E12 & 0.874 \\
\cline { 2 - 3 } & E13 & 0.741 \\
\cline { 2 - 3 } & E14 & 0.861 \\
\cline { 2 - 3 } & E1 & 0.748 \\
\hline & & 0.694 \\
\hline
\end{tabular}

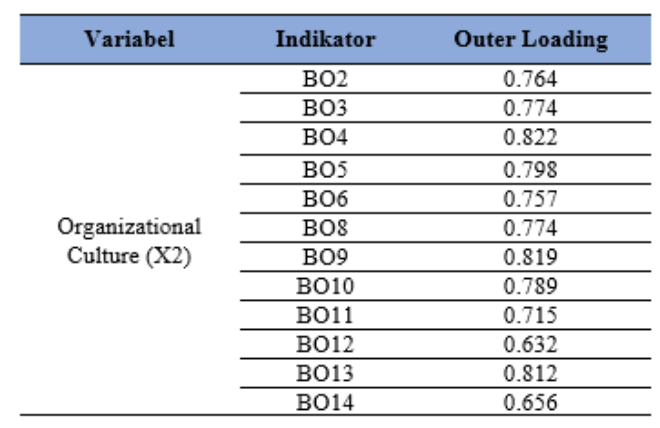

\begin{tabular}{ccc}
\hline Variabel & Indikator & Outer Loading \\
\hline & $\mathrm{K} 2$ & 0.820 \\
\cline { 2 - 3 } & $\mathrm{K} 3$ & 0.875 \\
\cline { 2 - 3 } Employee & $\mathrm{K} 4$ & 0.928 \\
\cline { 2 - 3 } Performance $(\mathrm{Y})$ & $\mathrm{K} 5$ & 0.951 \\
\cline { 2 - 3 } & $\mathrm{K} 6$ & 0.927 \\
\cline { 2 - 3 } & $\mathrm{K} 7$ & 0.715 \\
\cline { 2 - 3 } & $\mathrm{K} 8$ & 0.826 \\
\hline
\end{tabular}

Furthermore, the discriminant validity test was carried out based on the results of cross loading and declared valid.

Table 4. Discriminant Validity

\begin{tabular}{|c|c|c|c|c|c|}
\hline Variable & Indikator & IM & $\mathrm{OC}$ & $\mathrm{EE}$ & $\mathrm{EP}$ \\
\hline \multirow{8}{*}{$\begin{array}{l}\text { Intrinsic } \\
\text { Motivation } \\
\text { (X1) }\end{array}$} & M1 & 0.832 & 0.652 & 0.605 & 0.411 \\
\hline & $\mathrm{M} 2$ & 0.786 & 0.712 & 0.725 & 0.612 \\
\hline & M3 & 0.732 & 0.616 & 0.490 & 0.349 \\
\hline & M5 & 0.687 & 0.579 & 0.421 & 0.332 \\
\hline & M6 & 0.721 & 0.542 & 0.500 & 0.346 \\
\hline & M7 & 0.656 & 0.505 & 0.388 & 0.285 \\
\hline & M8 & 0.693 & 0.656 & 0.711 & 0.601 \\
\hline & M10 & 0.797 & 0.742 & 0.564 & 0.367 \\
\hline \multirow{12}{*}{$\begin{array}{c}\text { Organizational } \\
\text { Culture } \\
\text { (X2) }\end{array}$} & $\mathrm{BO} 2$ & 0.682 & 0.774 & 0.567 & 0.454 \\
\hline & $\mathrm{BO} 3$ & 0.707 & 0.822 & 0.584 & 0.418 \\
\hline & $\mathrm{BO} 4$ & 0.612 & 0.798 & 0.573 & 0.491 \\
\hline & $\mathrm{BO} 5$ & 0.628 & 0.757 & 0.517 & 0.389 \\
\hline & BO6 & 0.610 & 0.774 & 0.515 & 0.363 \\
\hline & BO8 & 0.649 & 0.819 & 0.585 & 0.500 \\
\hline & BO9 & 0.698 & 0.789 & 0.744 & 0.621 \\
\hline & BO10 & 0.706 & 0.764 & 0.534 & 0.333 \\
\hline & BO11 & 0.618 & 0.715 & 0.536 & 0.365 \\
\hline & BO12 & 0.577 & 0.632 & 0.468 & 0.362 \\
\hline & BO13 & 0.732 & 0.812 & 0.606 & 0.432 \\
\hline & BO14 & 0.587 & 0.656 & 0.761 & 0.627 \\
\hline
\end{tabular}

\begin{tabular}{|c|c|c|c|c|c|}
\hline Variable & Indikator & IM & $\mathrm{OC}$ & $\mathrm{EE}$ & $\mathrm{EP}$ \\
\hline \multirow{10}{*}{$\begin{array}{c}\text { Employee } \\
\text { Engagement } \\
\text { (Xmed) }\end{array}$} & E1 & 0.531 & 0.592 & 0.694 & 0.561 \\
\hline & E2 & 0.448 & 0.501 & 0.628 & 0.504 \\
\hline & E5 & 0.791 & 0.769 & 0.889 & 0.668 \\
\hline & E6 & 0.587 & 0.623 & 0.809 & 0.678 \\
\hline & E7 & 0.717 & 0.738 & 0.904 & 0.699 \\
\hline & E8 & 0.671 & 0.648 & 0.706 & 0.417 \\
\hline & E11 & 0.667 & 0.648 & 0.874 & 0.695 \\
\hline & E12 & 0.462 & 0.480 & 0.741 & 0.717 \\
\hline & E13 & 0.618 & 0.640 & 0.861 & 0.826 \\
\hline & E14 & 0.601 & 0.538 & 0.748 & 0.714 \\
\hline \multirow{7}{*}{$\begin{array}{c}\text { Employee } \\
\text { Performance } \\
\text { (Y) }\end{array}$} & $\mathrm{K} 2$ & 0.682 & 0.609 & 0.796 & 0.820 \\
\hline & $\mathrm{K} 3$ & 0.492 & 0.503 & 0.742 & 0.875 \\
\hline & $\mathrm{K} 4$ & 0.486 & 0.525 & 0.742 & 0.928 \\
\hline & $\mathrm{K} 5$ & 0.510 & 0.577 & 0.773 & 0.951 \\
\hline & K6 & 0.501 & 0.562 & 0.741 & 0.927 \\
\hline & K7 & 0.413 & 0.450 & 0.585 & 0.715 \\
\hline & K8 & 0.476 & 0.429 & 0.599 & 0.826 \\
\hline
\end{tabular}

Furthermore, the reliability test was carried out based on composite reliability and Cronbach's alpha with each condition being above 0.70 so that the instrument would be considered reliable.

Table 5. Reliability

\begin{tabular}{lcc}
\hline \multicolumn{1}{c}{ Variabel } & Composite Reliability & Cronbach's Alpha \\
\hline Intrinsic Motivation (X1) & 0.906 & 0.883 \\
\hline Organizational Culture (X2) & 0.943 & 0.934 \\
\hline Employee Engagement (Xmed) & 0.943 & 0.931 \\
\hline Employee Performance (Y) & 0.954 & 0.943 \\
\hline
\end{tabular}




\section{Evaluation of the Inner Model}

The first stage is to test the coefficient of determination by looking at the value of $\mathrm{R}$ Square, where Ghozali \& Latan classifies the R-Square value of $0.75,0.50$, and 0.25 into strong, moderate, and weak model.

Table 6. R-Square

\begin{tabular}{ll}
\hline \multicolumn{1}{c}{ Variabel } & R Square \\
\hline Employee Engagement (Xmed) & 0.657 \\
\hline Employee Performance (Y) & 0.692 \\
\hline
\end{tabular}

From these results, it can be concluded that the intrinsic motivation and organizational culture variables influence employee engagement and performance moderately. Furthermore, the Goodness of Fit Index (GoF) test is carried out, with the following calculations:

$$
\begin{aligned}
\text { GoF } & =\sqrt{ }(\text { AVE x R2 }) \\
& =\sqrt{ }((0.580+0.625+0.751+0.548) / 4) \times((0.657+0.692) / 2) \\
& =\sqrt{ }(0.626 \times 0,6745) \\
& =0.649
\end{aligned}
$$

From the calculation results, the GoF Index value is considered large because the value is more than 0.36 . Then the last one is to test the hypothesis, where the $t$ table value is obtained at 1.97377 with a significance level of significance $(\alpha)$ of 0.05 .

Table 7. Path Coefficients

\begin{tabular}{llcc}
\multicolumn{1}{c}{ Construct Correlation } & Original Sample & T Statistik & P Values \\
\hline Direct & & & \\
\hline $\begin{array}{l}\text { Intrinsic Motivation } \rightarrow \text { Employee } \\
\text { Performance }\end{array}$ & 0.324 & 2.971 & 0.000 \\
\hline $\begin{array}{l}\text { Intrinsic Motivation } \rightarrow \text { Employee } \\
\text { Engagement }\end{array}$ & 0.480 & 4.629 & 0.000 \\
\hline $\begin{array}{l}\text { Organizational Culture } \rightarrow \\
\text { Employee Performance }\end{array}$ & 0.371 & 3.289 & 0.000 \\
\hline $\begin{array}{l}\text { Organizational Culture } \rightarrow \\
\text { Employee Engagement }\end{array}$ & 0.388 & 3.579 & 0.000 \\
\hline $\begin{array}{l}\text { Employee Engagement } \rightarrow \\
\text { Employee Performance }\end{array}$ & 0.695 & 9.387 & 0.000 \\
\hline \begin{tabular}{l} 
Indirect \\
\hline $\begin{array}{l}\text { Intrinsic Motivation } \rightarrow \text { Employee } \\
\text { engagement } \rightarrow \text { Employee } \\
\text { Performance }\end{array}$
\end{tabular} & 0.430 & 3.214 & 0.000 \\
\hline $\begin{array}{l}\text { Organizational Culture } \rightarrow \\
\text { Employee engagement } \rightarrow \\
\text { Employee Performance }\end{array}$ & 0.347 & 3.831 & 0.000 \\
\hline \begin{tabular}{l} 
Total \\
\hline $\begin{array}{l}\text { Intrinsic Motivation } \rightarrow \text { Kinerja } \\
\text { Karyawan }\end{array}$
\end{tabular} & 0.754 & 4.202 & 0.000 \\
\hline $\begin{array}{l}\text { Organizational Culture } \rightarrow \\
\text { Employee Performance }\end{array}$ & 0.718 & 3.553 & 0.000 \\
\hline
\end{tabular}


The results showed that there was a positive and significant influence of intrinsic motivation on employee performance in line with the research of Ridwan Isya Luthfi, Heru Susilo and Muhammad Faisal Riza [9]. Intrinsic motivation also has a positive and significant effect on employee engagement in line with research by Aditia Rachmatullah [10], and employee engagement also has a positive and significant effect on employee performance in line with the research of Agnes Wahyu Handoyo and Roy Setiawan [11]. This is a continuation of intrinsic motivation that affects employee engagement, which ultimately affects employee performance. In this case employee engagement acts as a perfect mediator between intrinsic motivation and employee performance.

The research results also show that there is a positive and significant influence of organizational culture on employee performance in line with research by Alinvia Ayu Sagita, Heru Susilo and Muhammad Cahyo WS [12]. So, if the organizational culture is getting better, the employee's performance will also increase. In addition, the influence of organizational culture on employee performance can be stronger if mediated by employee engagement. In this study, it shows that organizational culture has a positive and significant effect on employee engagement in line with Muhammad Rizza Akbar's research [13], and as previously explained that employee engagement has a positive and significant effect on employee performance. And employee engagement strengthens the influence of organizational culture on employee performance.

\section{CONCLUSION}

From the research results it can be concluded that the direct influence of intrinsic motivation on employee performance gives positive but insignificant results. Nevertheless, in the indirect effect of mediating employee engagement, intrinsic motivation has a positive and significant effect on employee performance. So, it can be concluded that employee engagement perfectly mediates intrinsic motivation on employee performance. And the direct influence of organizational culture on employee performance gives smaller results than the indirect effect. So, it can be concluded furthermore that employee engagement partially mediates organizational culture on employee performance.

\section{REFERENCES}

Ridwan Isya Luthfi, Heru Susilo and Muhammad Faisal Riza, "The Effect of Motivation on Employee Performance", Journal of Business Administration (JAB), Vol. 13 No. August 1, 2014.

Aditia Rachmatullah, Ade Irma Susanty and Arif Partono, "THE EFFECT OF WORK MOTIVATION ON EMPLOYEE ENGAGEMENT", e-Proceeding of Management: Vol.2, No.3 December 2015

Ayu Sagita, Alinvia, Heru Susilo, Muhammad Cahyo WS 2018 "The Influence of

Organizational Culture on Employee Performance with Work Motivation as a Mediator Variable" (Study at PT Astra Internasional, Tbk-Toyota (Auto2000), Sutoyo Malang Branch), Journal of Business Administration (JAB)| Vol. 57 No.1 April. 
Agnes Wahyu Handoyo and Roy Setiawan, "EFFECT OF EMPLOYEE ENGAGEMENT ON EMPLOYEE PERFORMANCE AT PT. TIRTA REJEKI DEWATA”, AGORA Vol. 5, No.1, (2017)

Tjahjono, HK 2003. The Motivation To Work (Hezberg): Book Review. Journal of Management and Business Utilities, 11 (1)

Hofstede, G. 2001, Culture's Consequences: Comparing Values, Behaviors, Institutions, and Organizations across Nations, 2nd edn, Sage, Thousand Oaks, CA.

Schaufeli, WB, \& Bakker, AB (2004). Job demands, job resources and their

Relationship with burnout and engagement: A multi-sample study. Journal of Organizational Behavior, 1, 293-315

Sedarmayanti. 2009. Sumber Daya Manusia dan Produktivitas Kerja. Bandung: CV Mandar Maju.

Ridwan Isya Luthfi, Heru Susilo and Muhammad Faisal Riza, "The Effect of Motivation on Employee Performance", Journal of Business Administration (JAB), Vol. 13 No. August 1, 2014.

Aditia Rachmatullah, Ade Irma Susanty and Arif Partono, "THE INFLUENCE OF WORK MOTIVATION ON EMPLOYEE ENGAGEMENT", e-Proceeding of Management: Vol.2, No.3 December 2015.

Agnes Wahyu Handoyo and Roy Setiawan, "EFFECT OF EMPLOYEE ENGAGEMENT ON EMPLOYEE PERFORMANCE AT PT. TIRTA REJEKI DEWATA ”, AGORA Vol. 5, No.1, (2017).

Ayu Sagita, Alinvia, Heru Susilo, Muhammad Cahyo WS 2018 "The Influence of Organizational Culture on Employee Performance with Work Motivation as a Mediator Variable" (Study at PT Astra Internasional, Tbk-Toyota (Auto2000), Sutoyo Malang Branch), Journal of Business Administration (JAB) | Vol. 57 No.1 April.

Muhammad Rizza Akbar, "THE EFFECT OF ORGANIZATIONAL CULTURE ON EMPLOYEE ENGAGEMENT (STUDY ON EMPLOYEES IN PT.PRIMATEXCO INDONESIA IN BATANG)", Journal of Social and Industrial Psychology, JSIP 2 (1) (2013). 